Supplement of Atmos. Chem. Phys., 17, 4337-4353, 2017

http://www.atmos-chem-phys.net/17/4337/2017/

doi:10.5194/acp-17-4337-2017-supplement

(C) Author(s) 2017. CC Attribution 3.0 License.

(c) (i)

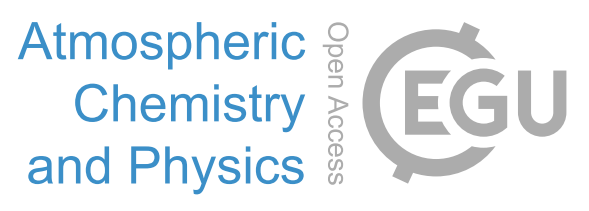

Supplement of

\title{
Role of vertical and horizontal mixing in the tape recorder signal near the tropical tropopause
}

\author{
Anne A. Glanville and Thomas Birner \\ Correspondence to: Thomas Birner (thomas.birner@colostate.edu)
}

The copyright of individual parts of the supplement might differ from the CC-BY 3.0 licence. 


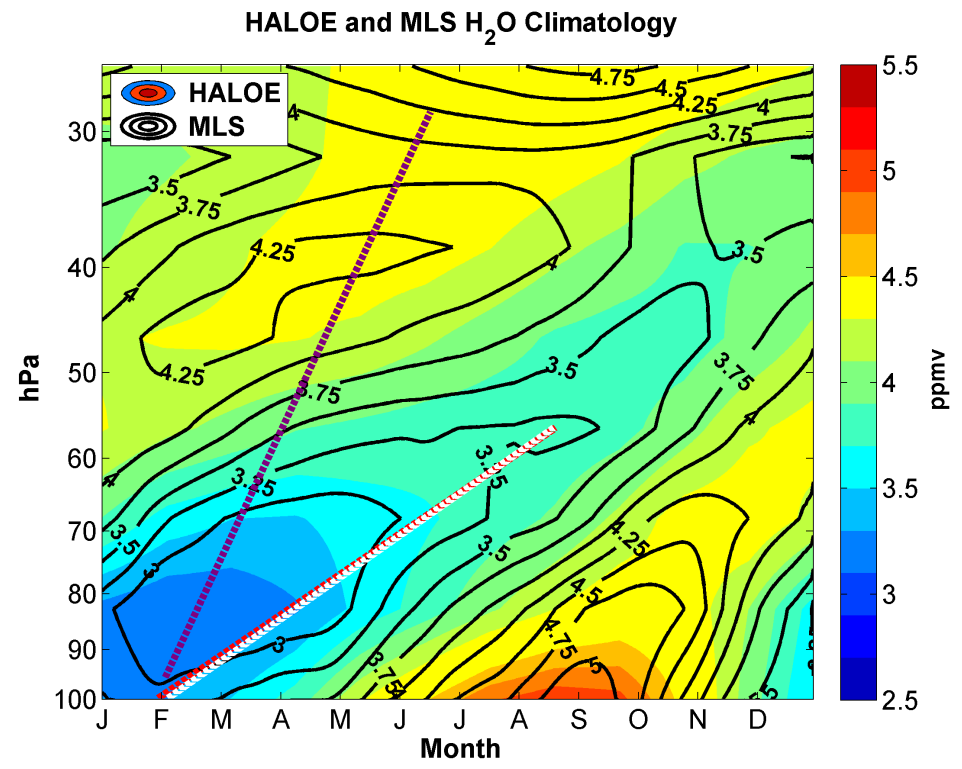

Figure S1. Complementary to Figure 2 in main paper: Climatological zonalmean tropical $\left(10^{\circ} \mathrm{S}-10^{\circ} \mathrm{N}\right)$ tape recorder signal (water vapor mixing ratio in ppmv) comparing HALOE (colors) with MLS (black contours). The dotted lines roughly indicate the evolution of the dry minima with time for MLS (red), HALOE (white), and ERA-i (purple, for reference).

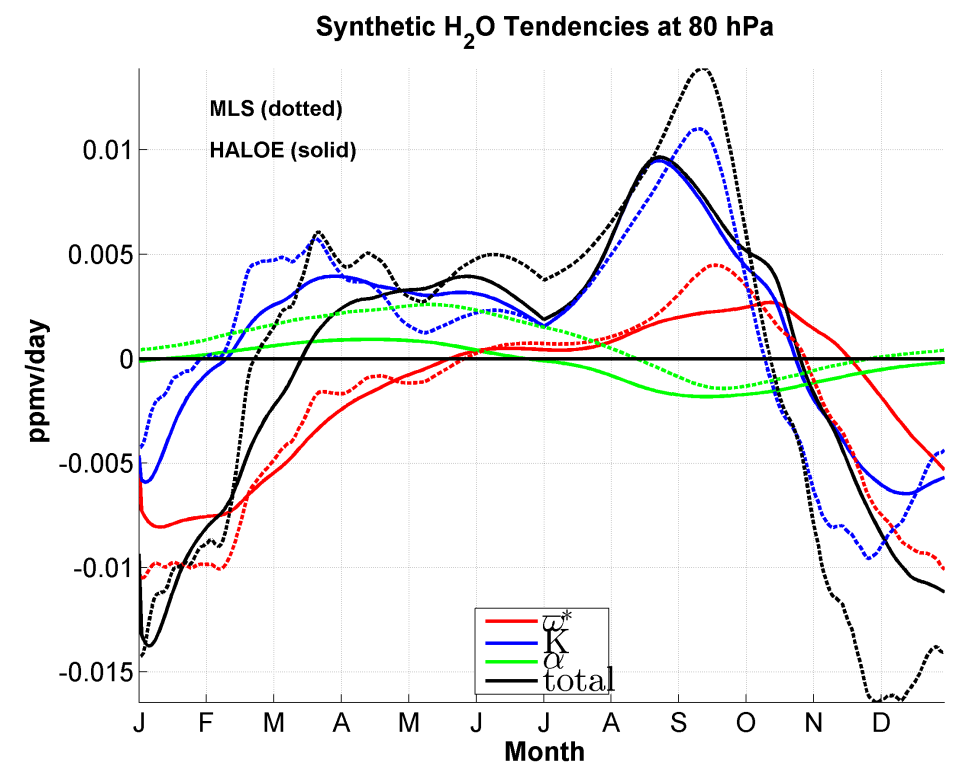

Figure S2. Complementary to Figure 7 in main paper: Contributions to the water vapor tendency (ppmv/day) at $80 \mathrm{hPa}$ from the best synthetic 1-d transport model solutions (corresponding to the white stars in Fig. 5 of main paper), comparing MLS (dotted) with HALOE (solid). 